Volume 12 | Issue 1

March 2021

\title{
Book Review: Global Indigenous Health: Reconciling the Past, Engaging the Present, Animating the Future
}

Chris Battiston

Women’s College Hospital, Canada, chris.battiston@wchospital.ca 


\title{
Book Review: Global Indigenous Health: Reconciling the Past, Engaging the Present, Animating the Future
}

\begin{abstract}
Literature about Indigenous health has dramatically increased over the past few years, which has made it difficult to stay current - this is a good thing. This uptick indicates that this work is getting attention it deserves. However, every so often a collection comes along that provides an essential overview of the work being done, and Global Indigenous Health: Reconciling the Past, Engaging the Present, Animating the Future is one such book. It examines the impacts and effects of health determinants on Indigenous Peoples from across the globe, including Micronesia, Alaska, and Canada.
\end{abstract}

\section{Keywords}

Data collection, determinants of health, Indigenous Peoples, colonialism, health, health policy, Indigenous health, decolonization

\section{Creative Commons License (a) $(\oplus \Theta \Theta$}

This work is licensed under a Creative Commons Attribution-Noncommercial-No Derivative Works 4.0 License. 


\title{
Book Review: Global Indigenous Health: Reconciling the Past, Engaging the Present, Animating the Future
}

\begin{abstract}
Henry, R., LaVallee, A., Van Styvendale, N., \& Innes, R. A. (Eds). (2018). Global Indigenous health: Reconciling the past, engaging the present, animating the future. University of Arizona Press. 352 pp. USD \$40 (paperback or eBook). ISBN: 9780816540204 . https://uapress.arizona.edu/ book/global-indigenous-health
\end{abstract}

Literature about Indigenous health has dramatically increased over the past few years, which has made it difficult to stay current - this is a good thing. This uptick indicates that this work is getting attention it deserves. However, every so often a collection comes along that provides an essential overview of the work being done, and Global Indigenous Health is one such book. It brings together authors from around the world and covers a variety of topics ranging from residential schools to the BCG immunization experiments. The editors have done a thorough job in encompassing diverse and varying perspectives. The authors come from a variety of disciplines and backgrounds, including Mãori (Simon Lambert), Abenaki and French Canadian (Judy Dow), and Caribbean Indian and Scottish (David MacDonald). They are all members of the Native American and Indigenous Studies Association (NAISA). In addition, the book draws upon a range of academic and lived-experience perspectives, which add to the breadth and allows for a more impactful reading. The book covers and aims to highlight issues from Indigenous Peoples from the settler nations of Canada, the US, Micronesia, and others.

A key theme of this book is the vast and significant health disparities faced by Indigenous Peoples across the globe-from Métis in Canada to Sámi of Northern Europe. The book also explores the resiliency and adaptability of Indigenous Peoples. Although each chapter focusses on a specific population or group of people, the themes of racism, inequity, and governmental roadblocks are counterbalanced by the stories of reconciliation, accountability, and working together with governments. This book directly addresses many challenging subjects, such as overall lower average levels of education (largely due to significant systemic barriers) to mercury-tainted drinking water and scientific experimentation without consent. The authors provide detailed accounts of the travesties these groups have faced historically, continue to face today, and the ways in which these factors will impact their health and well-being into the future. When the author is from the community that they are writing about (for example, Judy Dow and Paul DePasquale), the chapter ties the issue back to their own traditional healing methods and practices. The book focusses on four key themes using a social determinants of health approach: ethics and history; environmental and ecological health; impacts of colonial violence and Indigenous kinship; and Indigenous Knowledge and health activism. Always keeping colonization and the ongoing and lasting effects of settler colonialism as focal points, the editors overall and the authors in each chapter spotlight the legacy of trauma. The fact that Indigenous people around the world still face these issues is evidence of ongoing governmental and societal genocide. Despite this seemingly overwhelming negativity, the editors have illustrated throughout the book how Indigenous communities and advocates are working to bring health equity to Indigenous people. Because of the work done by these authors and many like-minded others, there are significant changes being made to policies and perspectives-and that is a definite positive. 
In the Introduction, the point is raised that, even though the UN has clearly called for countries to recognize and acknowledge Indigenous communities and their rights, many are not officially recognized or are lumped under umbrella terms and categories, "which affects how data and information, specifically related to health and well-being, is collected and collated" (p. 8). The editors refer to the example of the Métis in Canada, where research is "almost nonexistent because provincial health data about the Métis are not collated as such” (p. 8) because the group is often merged under the term Indigenous Peoples (which is officially comprised of First Nations, Inuit, and Métis). This is an example of epistemological violence and epistemic colonization (for detailed discussion see Shepherd, 2018; Teo, 2008, 2010). Epistemological violence can be defined as the "Othering" of someone as a result of how questions are asked or how data are collected and, by doing this, the person's identity is effectively "washed out." Epistemic colonization is a similar phenomenon, but at a higher level: It is the effective erasure of cultural or other forms of knowledge.

Canada has over 600 recognised First Nations, comprising over 1.6 million people (Indigenous and Northern Affairs, n.d.; Statistics Canada, n.d.) across all parts of the country. Although colonization and the ensuing racism have some common effects on Indigenous communities, there are going to be some key and critical differences. For example, despite the fact that both are in Ontario, the community of Mississaugas of the Credit First Nation, which is located near a major urban center, will have different concerns than Attawapiskat, which is one of the most northern communities. There will also be key differences between people living on reserve versus those living in an urban setting; however, colonization is still the root cause, and the differences and commonalities need definition in order to develop a deeper understanding, beyond just a superficial or academic one, of the impacts that colonization and systemic racism have had on the two groups. Someone living in the Innu community in Nain, Newfoundland, will have very different needs and requirements than someone living in downtown Toronto, Ontario, and this understanding is an important part of decolonization.

\section{Part I-Ethics and History}

The first chapter in this section, David MacDonald's "Indigenous Health in the Aftermath of Genocide," details the history of the residential school system in Canada. Almost 150,000 children were taken from their homes from the 1880s right up until the last institution closed in 1996, violating and devastating countless families and the collective consciousness of many communities. The system caused lasting and long-term trauma for Survivors and their families (see also Allan \& Smylie, 2015). The impacts on families includes higher rates stress-induced abuse; suicide and attempted suicide; and psychological issues, including anxiety, distress, and post-traumatic stress disorder (see also Bombay et al., 2014). Tying back to a social determinants of health perspective, there are cascade effects within these communities and people who have faced significant trauma often carry these impacts forward. Without proper social supports to bolster community healing, reconciliation and decolonization will not happen in an effective manner. Healing, decolonization, and reconciliation are linked because they cannot occur in isolation - they are interconnected, and settlers must participate in work on all three simultaneously. Settlers must learn about Indigenous communities and how ongoing racism is continues to affect Indigenous people today.

Seth Adema's chapter, "Helping His Brothers and Sisters Heal," focuses on the life and work of Art Solomon, an Anishinaabe man, of whom most settlers would not have heard, but who needs to be 
recognised. He dedicated his life to improving the lives of Indigenous people in Canada, working tirelessly to decolonize and expose the impact of settlers on Indigenous people in the Canadian prison system. His focus on Indigenous people in the prison system is important because it laid the groundwork for Indigenous-specific supports to be available in prisons. In an interview, Ryan Beardy, a Cree/Saulteaux man from Lake St. Martin First Nation who was sent to a youth detention center when he was 13, said, "when I took a good hard look at my values and belief systems and realized how wrong and off I was ... the culture really helped me" (cited in Monkman, 2018, para. 12). Indigenous youth make up $46 \%$ of incarcerated young people in Canada, while making up only $8 \%$ of the youth population, so providing them with supports and mechanisms for connecting back to their community is essential (Monkman, 2018).

Eleanor Louise Hadden's chapter, "BCG Tuberculosis Vaccine Experiment on Southeast Alaska Natives," hit particularly close to home for me as I received the BCG vaccine (although a different type than what was tested) when my family was living in the Middle East in the late 1970s. The history of the vaccine parallels other stories in medical research that are more commonly known (for example, Henrietta Lacks, ${ }^{1}$ and the medical experiments by the Nazis). The granddaughter of the study's original author was doing a 56-year follow-up and, like others in the medical community, assumed that the people in the community had consented to participate in the experiment, but they had not. I cannot imagine the psychological dissonance that she must have felt when she realised what had actually transpired and how it contributed to feelings of abandonment and resentment within the community. The regularity with which settlers assume that Indigenous people are there for whatever settlers have deemed necessary is a theme this book regularly revisits — arrogance, racism, and blatant disregard for any ethics create a clear pattern within colonialism.

Eugenics, the "scientific" attempt to show racial and ethnic superiority, has been used to justify a wide range of racist and colonial laws from South Africa to Canada. Judy Dow writes about the Vermont Eugenics Study (VES) in her chapter, "Understanding the Vermont Eugenics Study and its Impact Today." The VES was instituted in 1925 by a zoology professor who hired social workers to collect data on families living on the outskirts of Burlington, Vermont, whose lifestyle and culture he found "repugnant" and that he believed was hereditary. The study disrupted the lives of thousands of French, Catholic, and Indigenous people living in the area and, as Dow finds through her research, her family was directly impacted. It is critical to note that the VES, although started in 1925, continues to be used as a justification for a wide range of political and other colonizer-favoured goals.

\section{Part II-Environmental and Ecological Health}

The first chapter in Part II is the first that does not focus on North America. Simon Lambert's "Introduced Biotechnologies, Traditional Lands, and Indigenous Well-Being" looks at the Māori experience resisting expanding neocolonization, in which the New Zealand bioeconomy is absorbing and taking over Māori land and produce. Using the potato as an example crop, Lambert touches on how the introduction of the tuber in the late 1700s brought with it effects of colonization: certain crops were

\footnotetext{
${ }^{1}$ Henrietta Lacks was an African American woman who was diagnosed with cervical cancer in the late 1940s. During the diagnostic process, doctors found that her cells had a unique ability to live for extremely long periods. Without her knowledge or consent, these cells then became an integral part of medical research. This research continues to this day ("Henrietta Lacks: Science Must Right,” 2020).
} 
grown specifically to trade with the Europeans, rather than be eaten by the Māori. The potato then became a staple of the Maori economy, and they have now taken the production of the tuber to new levels. In this way, the Maori took something that was brought by the settlers and absorbed it into their culture - culminating in the incorporation of Tāhuri Whenua, or the National Maori Vegetable Growers Collective, in 2004. Lambert refers to the "humble spud" as an "innovation matrix that incorporates policy and technological and institutional innovations to enable the delivery of unique goods and services to a market economy" (p. 114).

The second chapter in this section, "USDA Foods, Indigenous Health, and Self-Sufficiency on Pohnpei, Micronesia" by Josh Levy, highlights the legacy of colonialism in the Oceanic region and the recent increases in non-communicable diseases such as diabetes, heart disease, and chronic kidney disease. Micronesia is, at the time of the chapter's writing, an independent country in "free association" with the United States (meaning the US provides annual funding, access to certain federal programs, and free immigration in exchange for land that they use for military purposes and to ensure there is no foreign military within the borders). The population was approximately 102,000, and Pohnpei, being the second most populated state, had 36,000 residents on 130 square miles of land; there is a high main island and seven populated outer islands. Overall, $32.1 \%$ of the adult population had diabetes, and $73.1 \%$ of the adult population was either overweight or obese. Pohnpei declared independence from the free association with the US in 1983, and the formulation of food sovereignty (through the work of Johnny Hadley and others) represents a model of Indigenous-centered community activism. This chapter exemplifies the effect of Indigenous-centered activism-Pohnpei is an example of what happens when the system is allowed to reset itself, allowing for the Indigenous population to be free of colonization. No longer reliant on the US, the people's health improved, which in turn affected all other aspects of their lives.

Paul Depasquale's chapter, "Manitoba Hydro's Promotional Materials as Colonialist Discourse," highlights how Manitoba Hydro, a Crown corporation that has actively worked against the best interests of Indigenous people, uses images of them as tools in a marketing campaign. Depasquale provides examples of advertisements (e.g., billboards, bus shelter advertisements) featuring Indigenous people and symbols (the eagle in particular) to make the campaign appear to have "approval" from Indigenous communities. The last line of the chapter highlights that "... thinking critically about the stories these images tell to and about Indigenous peoples is particularly important in the context of Manitoba Hydro's capital expenditure plans to spend $\$ 33$ billion on hydroelectric generating stations and transmission lines over the next two decades” (p. 145). Colonialism at its finest - appearing friendly and supportive on the one hand, while moving forward with the project on the other. Indigenous people in Manitoba must deal with provincially instituted racism, which increases stress and its chronic effects.

\section{Part III-Impacts of Colonial Violence and Indigenous Kinship}

The language is lovely. The language in child welfare is that the duty of care of a child welfare authority is to act in the capacity of a wise and compassionate parent. A wise and compassionate parent doesn't do all the things that happens to these kids. (p. 151)

This chapter, "Child Welfare: A Social Determinant of Health for Canadian First Nations and Métis Children," written by Caroline Tait, Robert Henry, and Rachel Loewen Walker, uses the example of 
Saskatchewan's child welfare services as a model for agencies in Canada. The above quote, from Joan Glode, former executive director of Mi'kmaw Family and Children's Services, highlights that the welfare authorities who are supposed to be acting as surrogate parents instead allow for the continuation of systemic and systematic racism. Emphasising that colonization is a social determinant of health, the authors show that "Indigenous status" should not be used as a determinant of health; rather, government and researchers should focus on "... the impact of those government policies enacted on Indigenous peoples [emphasis in original] that perpetuates health and social disparities" (p. 153). Child welfare services (theoretically) use a "threshold" model to apprehend children who have been abused and/or neglected. However, in practice, child welfare systems focus on First Nations and Métis groups, about whom they have preconceived misconceptions that assume they are less able to parent their children. The "benevolent culture of care" (p. 157) assumes that children taken by the State and put into foster care are put into environments that allow them to flourish. The respective life history research performed by Tait et al., however, showed that the effects of abuse and neglect carry forward for at least two generations, increasing the likelihood that they will become adults with various social and health issues.

"Oh, I think I will be a prostitute, break the law and go to prison!" (p. 174). This is how the chapter, "They Stole my Thunder," by Sharon Leslie Acoose and John Charlton, starts off. The colonial perspective seems to be that Indigenous women somehow want and plan to become prisoners, whereas White women have "poor circumstances" and are "victims of their environment" (see also Gilchrist, 2010; Jiwani \& Young, 2006). As a woman who has been imprisoned, Acoose is able to provide an account that is both very personal and evidence-based. She describes her journey from the stigmatized "criminal Indian woman" (p. 189), to finding other women from which to gain strength and support, to finally being able to say to themselves and to the world: This is who I am; I have re-found my thunder. This chapter brings attention to the needs Indigenous women in the penal system have, which can be addressed by supporting and collaborating with them to ensure their health. Given the complex treatment needs that many Indigenous women have during their incarceration, these needs are often inadequately addressed by the supports provided to the general population (see Adema's chapter in this volume for a culturally appropriate treatment program).

Margaretha Uttjek’s chapter, "Preventative Efforts to Address Violence Against Sámi Women and Children," looks at how the Indigenous people in Northern Europe (including Sweden, Norway, Finland, and Russia) are impacted by and deal with violence toward their women and children. Covering areas such as cultural and religious violence, Uttjek's research highlights that, even in a situation where Indigenous people are superficially similar to the colonizing race (in this case, generally having White skin and blonde hair), they face clear and deep effects of colonialism and oppression. Uttjek's research touches on psychospiritual violence, in which the Indigenous person's holistic identity is violated — this is something that other Indigenous groups face; yet, it was the first time I have seen it described in this way. The chapter provides seven systemic and governmental recommendations for dealing with the ongoing issue of violence against the Sámi, including a hotline, employing Sámi with social work education as experts (with associated pay increases), educating healthcare providers about the Sámi, and ensuring representation from Sámi scholars on research ethics and review boards.

"Uschiniichisuu Futures," Ioana Radu's contribution to the book, focusses on research conducted in the Cree Nation of Chisasibi, exploring the concept of healing as a way for the youth of the community to 
navigate identity. Radu highlights how current research on Cree youth focuses on, and amplifies, the racist colonial perspective of dysfunction, such as alcohol and drug abuse, dropping out of school, interpersonal violence, etc., but in fact research looking at strengths and resiliency also needs to be supported. Highlighting examples that are counterpoint to the colonial perspective of Cree youth, Radu shows that the majority are actually contributing members of their society, and how activities that are both youth and culturally focussed (e.g., ceremonial participation, rap battles, and spending time in the bush) can contribute to the healing within the community.

\section{Part IV-Indigenous Knowledge and Health Activism}

The first chapter of the last section touches on the theme of systemic racism as it relates to health policy, which was covered in a previous chapter in this volume, but this final section takes another approach. Alicia Powell and Chelsea Gabel's chapter, “Addressing Inequalities," discusses disparities between settlers and Indigenous people within health policy by digging into service-level issues, from hospitalbased discrimination to inadequately supplied medical clinics on reserves and in northern communities. The authors provide numerous examples of these incongruencies, but the one that sticks out for me is the case of Brian Sinclair, an Indigenous man who died in the waiting room at Winnipeg Health Sciences Center. He died as a result of a bladder infection, without receiving any treatment, because hospital staff thought he was intoxicated and not sick. This is an example of the implicit racism and severe biases in clinical reasoning that Indigenous people face on a regular basis and that healthcare systems need to address. The chapter touches on urban Indigenous health and how it differs from that on reserve in terms of healthcare providers' perceptions (ill versus intoxicated), inclusion of traditional and culturally safe options, and the likelihood of experiencing discrimination.

"Wiçozani Wašte (Good Life)" is Mark Ruml's fascinating analysis of "Indigenous religious traditions" (p. 257). He uses his personal experience of being mentored by Arthur Amiotte, a Lakota man, and how this mentorship completely re-directed his path in life. Out of respect to the teachings in this chapter, I will not go into specifics, but there were things that I learned in this chapter that changed my perspective on life in a profound way. The chapter reinforces why the conversation around decolonization of healthcare needs to include all aspects of Indigenous culture, including spiritual traditions. For example, when writing hospital policy, understanding the importance of Indigenous traditions would require consideration about how tobacco could be burned if requested by an Indigenous person. This approach is important because psychospiritual (to use Uttjek's term) well-being is part of being healthy and providing supportive health care.

The second last chapter, Lisa Tatonetti's "Carole laFavor's Indigenous Feminism and Early HIV/AIDS Activism," brings attention to the life and work of Carole Lafavor, an Anishnaabe HIV/AIDS activist, novelist, and nurse. When the US Government sent out a mass mailing entitled "Understanding AIDS" to every residence in the US, it contained laFavor's words. She was not only a key voice in queer Indigenous literature, but also in the rise of Indigenous-centered HIV/AIDS education and activism. laFavor's work in healthcare ranged from sending medical supplies to Wounded Knee to speaking out about the issue of missing and murdered Indigenous women. She spoke often about the ways in which settler colonialism infiltrates all aspects of Indigenous women's lives, and she explored this theme into her fiction: Her characters often faced violence that was overlooked and ignored by authorities. Through the chapter, laFavor's "fight for Indigenous health sovereignty" (p. 24), particularly in the context of 
HIV/AIDS in Indigenous communities, is an example of the tireless, constant fighting that has to be done to make sure Indigenous people's needs are taken care of. This is a fight that in an ideal world people would be unnecessary because people would be treated equitably within health systems and the broader society. In 2011, laFavor passed away; yet her fight for Indigenous health autonomy continues to this day.

The final chapter in the book, “Traveling the Möbius Strip” by Barbara Fornssler et al., is possibly the most important chapter in the collection as it is a reflection on the "thoughts, concerns, responses and visioning of Indigenous and non-Indigenous members of a research team” (p. 295) working on a decolonization project. A key concept in the chapter is Two-Eyed Seeing, which the authors describe as the weaving together of local Indigenous Knowledge with Western scientific knowledge, while keeping the integrity of the Indigenous methodologies and knowledge intact. The authors touch on how nonIndigenous people can ally themselves with Indigenous communities in the short term, as well as strategies for supporting the development of non-Indigenous research accomplices over the long term. These strategies include encouraging honesty, maintaining separateness, and extend gifts. This chapter is one I will refer to often and repeatedly, looking for its wisdom and teachings.

\section{Conclusion}

As a privileged settler working as a database administrator for a hospital-based research institute in Toronto, Canada, this book's themes opened my eyes to the need to be more aware of data collection methods, including more inclusive demographic questions, cultural and racial sensitivity, and how to be a better ally overall. This is the type of book that I simultaneously want to rush through to pick up the key pieces without being impacted by the constant barrage of trauma and racism, and to read slowly, methodically, and carefully in order to ruminate on and honour those that have lived these experiences.

Intersectionality looks at various demographic features of a person and allows for the full understanding of that person, both as an individual and within the community or population being studied (Crenshaw, 1989; Hankivsky et al., 2014). Having this framework as a component to this book would have elucidated and disentangled some of the issues and provided an interesting perspective by examining different impacts on women as compared to the men, for example. The inclusion of a chapter on food deserts, perhaps using the Canadian Far North as an example of a place where food prices are significantly higher than the rest of the country (e.g., \$45 for half a watermelon) and yet many people do not have the economic resources to offset these costs, would be valuable. Both intersectionality and food deserts play a part in determining a person's health status but are discussed less often in healthcare literature. I believe an intersectionality-based framework should be implemented as a standard practice to ensure information like this is not only collected but appropriately analysed and reported.

Intersectionality is not a solution - it is a tool for looking at an issue, so it requires active engagement on the part of the author or researcher. I believe it is for this reason that intersectionality is overlooked or ignored for most issues, which is unfortunate as it would provide a clearer picture of what is happening.

Although the title of this book is Global Indigenous Health, covering places such as Canada, the US, Micronesia, New Zealand, and Northern Europe, to be truly "global" chapters on African, Central and South American, and Middle Eastern decolonization and Indigenous health are needed. Having said 
that, this book has successfully contributed to the literature advocating for fundamental change, and I hope that healthcare researchers, practitioners, and administrators will add this book to their repertoire.

Overall, I found this book to be an important read that has expanded my understanding of the ongoing effects of colonization. This book should provide a starting point for anyone working in healthcare to grasp why colonialism, racism, and the settler mindset need to be discussed, understood, and dismantled in order to achieve health equity.

\section{References}

Allan, B., \& Smylie, J. (2015). First Peoples, second class treatment: The role of racism in the health and well-being of Indigenous Peoples in Canada. The Wellesley Institute. http://www.wellesleyinstitute.com/wp-content/uploads/2015/02/Summary-First-PeoplesSecond-Class-Treatment-Final.pdf

Bombay, A., Matheson, K., \& Anisman, H. (2014). The intergenerational effects of Indian residential schools: Implications for the concept of historical trauma. Transcultural Psychiatry, 51(3), 320338. https://doi.org/10.1177/1363461513503380

Crenshaw, K. (1989). Demarginalizing the intersection of race and sex: A Black feminist critique of antidiscrimination doctrine, feminist theory and antiracist politics. University of Chicago Legal Forum, 1989(1). http://chicagounbound.uchicago.edu/uclf/vol1989/iss1/8

Gilchrist, K. (2010). "Newsworthy” victims? Exploring differences in Canadian local press coverage of missing/murdered Aboriginal and White women. Feminist Media Studies, 1O(4), 373-390. https://doi.org/10.1080/14680777.2010.514110

Hankivsky, O., Grace, D., Hunting, G., Giesbrecht, M., Fridkin, A., \& Rudrum, S. (2014). An intersectionality-based policy analysis framework: Critical reflections on a methodology for advancing equity. International Journal for Equity in Health, 13(1), 119. https://doi.org/10.1186/s12939-014-0119-x

Henrietta Lacks: Science must right a historical wrong [Editorial]. (2020, September 1). Nature, 585(7). https://doi.org/10.1038/d41586-020-02494-z

Indigenous and Northern Affairs Canada. (n.d.). Welcome to First Nation profiles. https://fnpppn.aadnc-aandc.gc.ca/fnp/Main/index.aspx?lang=eng

Jiwani, Y., \& Young, M. (2006). Missing and murdered women: Reproducing marginality in news discourse. Canadian Journal of Communication, 31, 895-917. https://doi.org/10.22230/ cjc. $2006 \mathrm{v} 3 \ln 4 \mathrm{a} 1825$ 
Monkman, L. (2018). Indigenous incarceration rates: Why are Canada's numbers so high and what can be done about it? CBC News. https://www.cbc.ca/news/indigenous/indigenous-incarcerationjustice-system-panel-1.4729192

Shepherd, N. (2018). Epistemic decolonization. In C. Andersen, B. T. Knudsen \& C. Kølvraa (Eds.), Keywords: Anthology exploring the keywords of colonial heritage. http://keywordsechoes. com/

Statistics Canada. (n.d.). Statistics on Indigenous Peoples. https://www.statcan.gc.ca/eng/subjectsstart/indigenous_peoples

Teo, T. (2008). From speculation to epistemological violence in psychology: A critical-hermeneutic reconstruction. Theory \& Psychology, 18(1), 47-67. https://doi.org/10.1177/ $\underline{0959354307086922}$

Teo, T. (2010). What is epistemological violence in the empirical social sciences? Social and Personality Psychology Compass, 4(5), 295-303. https://doi.org/10.1111/j.1751-9004.2010.00265.x 